\title{
Stem Cell Therapy for Retinopathy of Prematurity
}

Angela Ka Wai Lai', Zhong Jie Fu' ${ }^{1}$ and Amy CY Lo ${ }^{1,2 *}$

${ }^{1}$ Department of Ophthalmology, Li Ka Shing, Faculty of Medicine, The University of Hong Kong, Hong Kong, China

${ }^{2}$ Research Center of Heart, Brain, Hormone and Healthy Aging, Li Ka Shing Faculty of Medicine, The University of Hong Kong, Hong Kong, China

\begin{abstract}
Retinopathy of Prematurity (ROP) is a leading cause of childhood blindness that severely affecting the quality of life of these children. Few treatment options are available but without favorable outcomes. Stem cell therapy, through its proven potential in tissue regeneration, provides an attractive therapeutic approach in treating ROP and thereby restoring vision.
\end{abstract}

Keywords: Neuroprotection; Angiogenesis; Neovascularization; Retinal degeneration; Photoreceptor; Retina; Oxygen induced retinopathy

\section{Introduction}

Retinopathy of Prematurity (ROP), first described in the 1940s [1], is a common ocular disease that occurs in premature babies and is the major cause of severe visual impairment or blindness in children living in the high- and middle-income countries [2]. The incidents of ROP not only affect the quality of life of these children in the rest of their lives, but can also cause numerous medical and economic burdens in the society. Effective and safe treatments are, therefore, vital. The emergence of stem cells provides an excellent therapeutic approach in ocular disease due to its potential in tissue regeneration by replacing the damaged cells as well as evoking paracrine signals to the neighboring cells, and thereby restoring vision. In this review, the potential application of stem cell therapy in ROP will be discussed.

\section{Overview of Vision}

The eye is a unique and well-designed organ that allows us to transduce light into signals and proceed to images in the brain, resulting in perception of "vision". Such a process involves a precise coordination of various components. Firstly, light passes through the cornea and is gathered and focused via the lens onto the retina, which is highly vascular and consists of layers of various cell types. In the back of the retina, photoreceptors sense the light and transduce it into electric signals that are then transmitted through bipolar cells to the retinal ganglion cells (RGCs) located at the inner retina. These signals subsequently travel along the axons of RGCs, which is also known as the optic nerve, to the visual cortex of the brain where images are translated. Vision loss can be resulted from defects or abnormalities in any part of the above pathway, such as genetic defects, degeneration and chemical or physical trauma.

\section{Structure of Retina}

The retina is highly vascularized and consists of various types of cells that are precisely organized into three layers of neural cell bodies: (1) the outer nuclear layer (ONL) filled with the nuclei of photoreceptors, (2) the inner nuclear layer (INL) housing the nuclei of bipolar, horizontal and most of the amacrine cells, as well as (3) ganglion cell layer (GCL) including the nuclei of RGCs and some displaced amacrine cells. In addition, axons and terminal endings of these retinal neural cells form two synaptic layers: the outer plexiform layer (OPL) and the inner plexiform layer (IPL) [3] (Figure 1).

Dual blood supply is present in the retina to support its daily metabolic demand: the choroidal vessels provide oxygen and nutrients to the photoreceptors located at the outer most layer of the retina while other inner retinal cells, such as RGCs and Müller cells, are nourished by the intra-retinal circulation [4]. These retinal micro-vessels contain an inner lining of non-fenestrated endothelial cells surrounded by pericytes and glial processes. More importantly, all of these components are joined together by tight junctions in order to maintain the integrity of the blood retinal barrier [5].

\section{Retinopathy of Prematurity}

ROP, which is a major complication of preterm births, contributes to the leading cause of childhood blindness. The prevalence of ROP is associated with low birth weight, low gestational age, supplemental oxygen therapy [6], low insulin-like growth factor (IGF-1) level [7], and genetic mutation [8]. Due to the increased survival of extreme low birth weight infants ( $\leq 1000 \mathrm{~g}$ ) with improved neonatal care, the risk for ROP has also been increased [9].

ROP is a biphasic disease with a first phase of vessel growth cessation and a second phase of vessel proliferation (also known as "neovascularization"). In human, the development of retinal vasculature starts from the $16^{\text {th }}$ week of gestation and finishes just before term, i.e. the $40^{\text {th }}$ week of gestation, in a central-to-peripheral manner [10]. The relative hyperoxia of the extra-uterine environment with or without supplemental oxygen during hospitalization, together with a deficiency of autoregulation, result in an increase of free oxygen radical and a decrease of vascular endothelial growth factor (VEGF) in the premature retina and subsequently the regression of developed retinal vessels. Incomplete development of the retinal vasculature therefore limits retinal blood circulation, leading to a peripheral avascular a vascular zone in the retina of preterm infants. However, as the infants grow, the non-vascularized retina becomes increasingly metabolically active and more oxygen is in turn required, resulting in tissue hypoxia which then stimulates vessel proliferation. In severe cases, this proliferation triggers

*Corresponding author: Amy CY Lo, Department of Ophthalmology, Li Ka Shing The University of Hong Kong, L6-30 Laboratory Block, 21 Sassoon Road, Pokfulam, Hong Kong, China, Tel: +852-39179859; Fax: +852-28170491; E-mail: amylo@hku.hk

Received September 15, 2013; Accepted November 18, 2013; Published November 20, 2013

Citation: Lai AKW, Fu ZJ, Lo AC (2013) Stem Cell Therapy for Retinopathy of Prematurity. Anat Physiol 3: 126. doi:10.4172/2161-0940.1000126

Copyright: $\odot 2013$ Lai AKW, et al. This is an open-access article distributed unde the terms of the Creative Commons Attribution License, which permits unrestricted use, distribution, and reproduction in any medium, provided the original author and source are credited. 


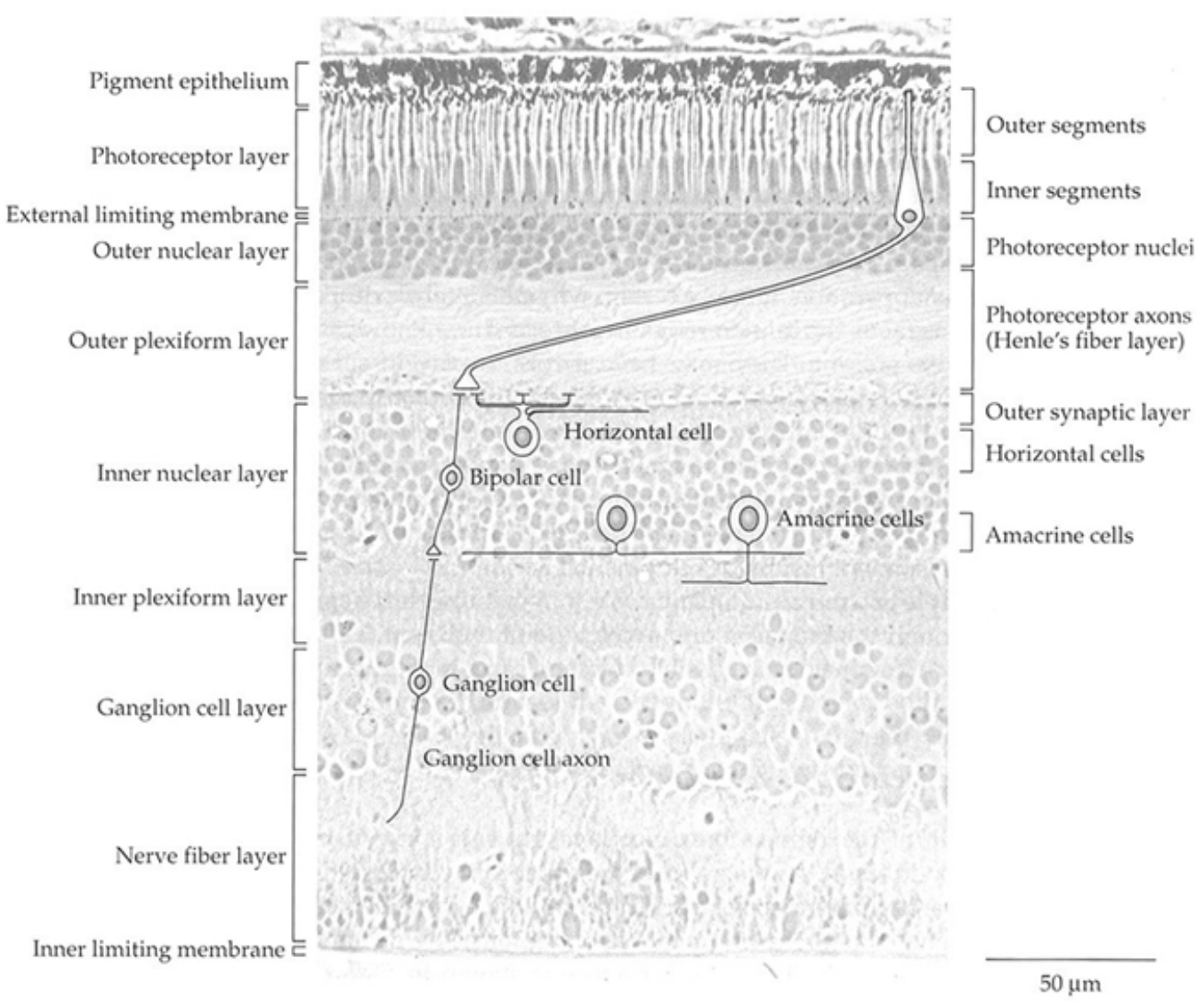

Figure 1: Layers of the human retina. The retina mainly contains three layers of neural cell bodies (from basal to vitreal): ONL with nuclei of photoreceptors; INL with nuclei of horizontal cells, bipolar cells and most amacrine cells; GCL with nuclei of RGCs and some displaced amacrine cells. In addition, the axons and terminals of the retinal neurons form two synaptic layers: OPL and IPL [3].

uncontrolled pathological regrowth of the overstated, disorganized, fragile, and leaky vessels from the retina into the vitreous, proceeding to hemorrhage and cloudy vision. Fibrous scar is eventually formed and retraction of which can result in detachment of retina from the retina pigment epithelium and even blindness if remains untreated $[4,6,8,11]$. In general, the extent of human ROP is categorized into five stages based on the vasculature [12,13] (Figure 2 and Table 1).

In addition to the vascular abnormalities, reduced visual acuity [14,15] and neuronal changes [16-19] have also been reported. Alterations of electroretinographic (ERG) responses have been reported in infants and children with a history of ROP. Lower saturated amplitude, decreased sensitivity and prolonged deactivation of rod photoreceptors were observed [16-20] and these deficits appeared to persist long after ROP has been resolved $[17,19]$. In addition, attenuated post-receptor responses were also present. Although these deficits could be improved in children with a history of mild ROP, they remained in the severe cases $[16,19,21]$.

\section{Current Treatments}

Current treatments of ROP aim to target the pathological neovascularization and include retinal cryotherapy, laser photocoagulation and anti-VEGF therapy $[6,11,12]$. Retinal cryotherapy and laser photocoagulation have been proven to be effective in ablation of the avascular immature retina in infants with active ROP [12]. A 15-year follow-up study of cryotherapy has shown a $>40 \%$ decreased unfavorable structural outcomes and a $30 \%$ decreased unfavorable visual outcomes [13]. However, side effects such as lid edema, laceration, hemorrhage of conjunctiva as well as preretinal and vitreous hemorrhage have been observed in this treatment [22]. Later, a shift from cryotherapy to laser photocoagulation was adopted due to better structural and functional outcomes [22]. Laser therapy is more convenient and technically easier, with less ocular and systemic adverse effects as well as reduced lesions to the external eye surface and sclera, and therefore used as a mainstay therapy. However, considerable complications of cornea, iris and lens burns, corneal edema, cataract formation, intraocular hemorrhage, and choroidal rupture have been reported due to laser treatment $[8,22]$.

Over the last two decades, extensive research has focused on the development of ROP. It is found that neovascularization is partly resulted from an up-regulation of VEGF; therefore, intravitreal injection of specific anti-VEGF antibody can potentially neutralize the excessive amount of VEGF and may ameliorate the pathological vessel sprouting. The off-label use of the VEGF antibody, e.g. bevacizumab, is currently tested in clinical trials in neovascular retinopathy such as age-related macular degeneration, diabetic retinopathy and retinal vein occlusion $[8,23]$. Small-sized clinical trials of bevacizumab in ROP have also 


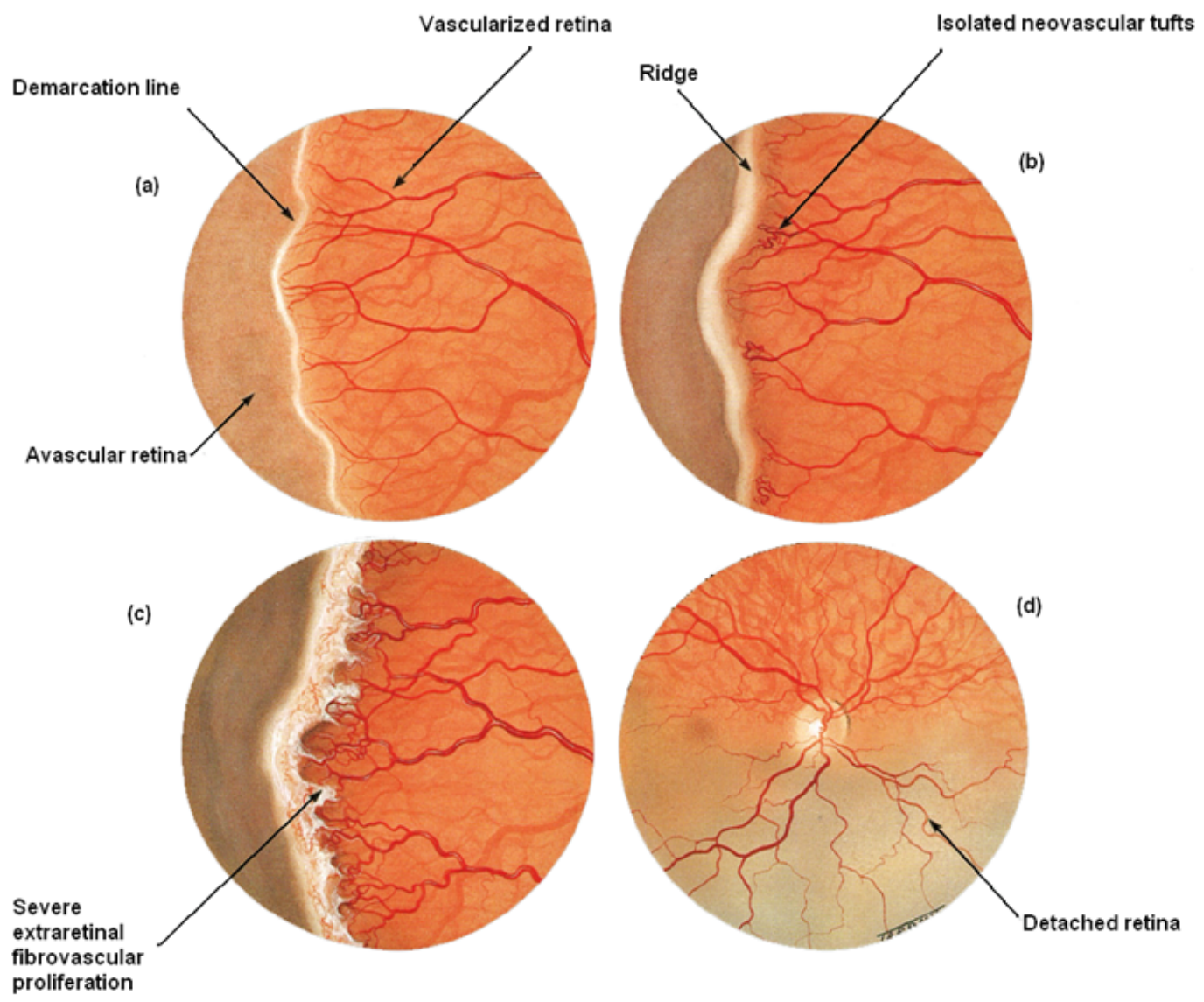

Figure 2: Progression of retinopathy of prematurity. (a) A thin, tortuous, grey-white line is formed and separates the avascular immature peripheral retina from the vascularized posterior retina. (b) As ROP progresses, the demarcation line develops into a ridge of tissue. Blood vessels enter the ridge and small isolated neovascular tufts may be seen. (c) Neovascular vessels extend from the retina into the vitreous due to the fibrovascular proliferation. (d) The progression of fibrovascular proliferation leads to retinal detachment [12].

\begin{tabular}{|c|c|}
\hline $\begin{array}{l}\text { Progression } \\
\text { of ROP }\end{array}$ & Characteristics \\
\hline Stage 1 & $\begin{array}{l}\text { A thin, tortuous, grey-white demarcation line is formed between } \\
\text { the vascular and avascular retina }\end{array}$ \\
\hline Stage 2 & $\begin{array}{l}\text { A white or grey ridge is developed from demarcation line and small } \\
\text { isolated neovascular tufts are observed posterior to it }\end{array}$ \\
\hline Stage 3 & $\begin{array}{l}\text { Neovascular vessels extend from the retina into the vitreous due } \\
\text { to extraretinal fibrovascular proliferation; hemorrhage of blood } \\
\text { vessels is observed in both of the retina and vitreous }\end{array}$ \\
\hline Stage 4 & $\begin{array}{l}\text { Partial retinal detachment from the extreme periphery into the } \\
\text { central retina }\end{array}$ \\
\hline Stage 5 & Total retinal detachment \\
\hline
\end{tabular}

been conducted. Decreased pupillary rigidity and complete regression of retinal neovascularization were observed after intravitreal injection of bevacizumab while the side effects of laser therapy such as retinal scarring were avoided [23]. However, another clinical trial reported leakage of intravitreal bevacizumab into the general circulation, which significantly decreased plasma VEGF even after seven weeks [24]. The use of anti-VEGF therapy in ROP is still uncertain owing to the controversial results in the above studies and missing long-term clinical data [25].

In severe cases of ROP involving retinal detachment, scleral buckling procedure with or without vitrectomy is applied, although the resulting visual outcome is usually poor [12].

\section{Animal Model of ROP: Oxygen-Induced Retinopathy}

In order to investigate the pathogenesis of ROP, various animal models of oxygen-induced retinopathy (OIR) have been applied in several species including mice, rats, dogs, cats and pigs [26]. In brief, newborn animals are exposed to hyperoxia and returned to room air, resulting in relative hypoxia and neovascularization that mimic the two phases of human ROP. Both mouse and rat models of OIR are commonly used for investigating vascular and neuronal changes after hyperoxic exposure. In the mouse model, postnatal day 7 (P7) neonatal mice with their nursing dams are put into a $75 \%$ oxygen chamber for five days (P12) and then returned to room air [27]. In the rat model, new-born pups (P0) with their mother are placed into an incubator where oxygen is cycled between $50 \%$ and $10 \%$ every 24 hours for fourteen days [28].

In the mouse model of OIR, vessel loss in the central area of retina is observed immediately after five days of hyperoxic exposure (P12). Neovascularization extending from the inner retina into the vitreous begins at two days after the return to room air (P14), peaks on P17 and is gradually regressed and spontaneously resolved by P25 $[27,29]$ (Figure 3). In the rat model of OIR, blood vessel regression is observed in the peripheral area of the retina on P14 and strong preretinal neovascularization is observed on P18 [28]. Besides the vascular changes, neuronal changes are also observed in these OIR models. In addition to the altered ERG responses in human as described earlier, 


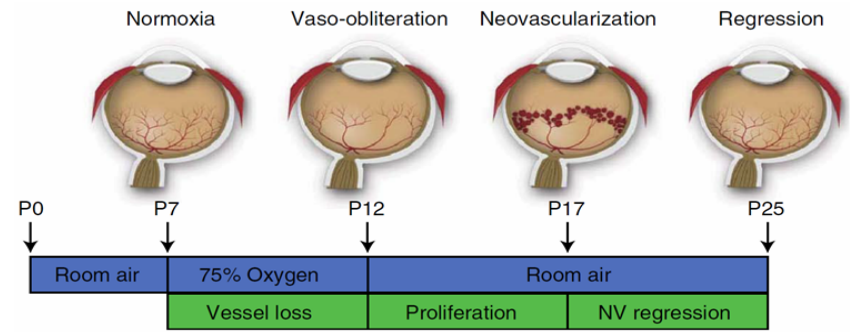

Figure 3: Schematic diagram of the mouse OIR model. Neonatal mice and their nursing dam are placed into a $75 \%$ oxygen chamber from postnatal day 7 (P7) for five days. During this period, the growth of retinal vessels is inhibited resulting in significant vessel loss in the central area of the retina. The animals are then returned to room air on P12. Hypoxia-associated pathological neovascularization begins at two days after the return to room air (P14) and reached its maximum on P17. Neovascularization is gradually regressed and spontaneously resolved by P25 [29].

neuronal dysfunction of rods and inter-retinal neurons has also been shown in rat models of OIR. Deficits in rods and post-receptors ERG responses were observed [15,30-32]. Consistent with the pathology in human ROP, the sensitivity of post-receptors can be recovered but not for rod photoreceptors [31]. In addition, morphological studies showed disrupted rod outer segment and neurochemical changes in bipolar and amacrine cells $[15,30]$. Moreover, a small loss of rod photoreceptor ERG amplitude and a significant loss of post-receptor ERG amplitude together with significantly reduced INL and IPL thickness have been observed in a mouse model of OIR [33].

Although the rat OIR model mimics human ROP with a peripheral avascular zone, the mouse model of OIR is sometimes more preferred due to easier genetic manipulation, which provides a powerful tool for pathogenetic investigations [34]. In addition, the retinal vasculature developmental stages from the superficial layer to the deep layer in mouse are well described. Most importantly, the stages that occur within the two weeks after birth in mouse approximate to those in premature infants at $16^{\text {th }}$ to $20^{\text {th }}$ weeks of gestation [27]. These characteristics facilitate the mouse OIR model as a convenient and most widely used animal model to study ROP as well as other ischemia-associated retinopathy, such as diabetic retinopathy and retinal vein occlusion [35].

\section{Ocular Stem Cells}

A variety of region-specific ocular stem cells were being identified since the 1970s. Several subtypes of stem cells were discovered in the limbus (also called corneal endothelium) [36-38], conjunctiva and trabecular meshwork $[39,40]$ in the anterior segment. Long term clinical studies showed that transplantation of autologous limbal stem cells obtained from the healthy eye could heal the damaged cornea with limbal stem cell deficiency resulting from severe ocular surface burns, microbial infection, chemotherapy and inflammatory diseases $[41,42]$.

In the posterior segment, retinal progenitor cells were also identified in the pigmented ciliary margin of adult mouse retina [43] and in human fetal retina at the $13^{\text {th }}$ week of gestation [44]. A sub-population of Müller stem cells was also identified in the human retina. Spontaneous immortalization was observed in these cells under optimal condition in vitro, generating the Moorfields/Institute of Ophthalmology (MIO) cell lines [45-47]. It was shown that these MIO cells could migrate into the ONL and express rhodopsin (a marker of photoreceptor cells), into the INL and expressed $\mathrm{HuD}$ (a marker of ganglion cells), as well as into the GCL and express calretinin (a marker of ganglion cells and amacrine cells) at 14 days after sub-retinal injection in normal neonatal Lister hooded rats [46] (Table 2). Moreover, a population of very small embryonic/epiblast-like stems cells (Sca- $1^{+}{ }^{+}$in ${ }^{-C D} 45^{-}$), which amounted to $1.5 \%$ of neonatal mouse retina, was identified [48]. These cells not only had the ability to differentiate into the eye lineages but also could differentiate into cells expressing markers of the three embryonic layers in vitro.

\section{Stem Cells in ROP Patients}

A clinical study evaluated the circulating stem cell populations in preterm infants with and without ROP at 10 weeks after delivery [49]. Two populations, namely very small embryonic-like stem cells (VSEL-SCs, LinCXCR4 ${ }^{+} \mathrm{CD} 45^{-}$) and endothelial progenitor cells (EPCs, CD $34^{+} \mathrm{CD} 133^{+} \mathrm{CD} 144^{+}$) were found to be increased in the peripheral blood collected from the preterm patients. In patients with ROP, the amount of these EPCs was significantly higher when compared with those without ROP. Yet, no difference was observed in the population of circulating cells enriched in hematopoietic stem cells $\left(\mathrm{Lin}^{-} \mathrm{CXCR} 4^{+} \mathrm{CD} 45^{+}\right)$amongst the preterm infants with or without ROP and the full-term controls. The authors suggested that the elevation of circulating VSEL-SCs in the preterm infants could be the result in response to hypoxia in ROP, although they did not rule out the possibility that such increase could be associated with the physiological conditions in immature infants. They also hypothesized that the systemic EPC mobilization was also involved during neovascularization in the proliferative phase of ROP and normal vascularization of the retina of individual without ROP; however, whether such increment of EPC was the cause or consequence of ROP development was still unknown.

It has been reported that VSEL-SCs are small primitive cells with a cell size of 3-5 $\mu \mathrm{m}$ in human cord blood-derived cells and of $2-4 \mu \mathrm{m}$ in mouse bone marrow cells. These cells have a high nucleus-to-cytoplasm ratio, with euchromatin and diploid number of chromosomes in the nucleus surrounded by a tiny rim of cytoplasm [50]. VSEL-SCs are present in umbilical cord blood [51], bone marrow, brain and other organs $[52,53]$. They express early embryonic transcription factors, such as octamer-4 (Oct-4), NANOG, REX, and stage-specific embryonic antigen (SSEA-1) [50,52], suggesting that they are deposited during embryogenesis and therefore, can be used as a source of pluripotent stem cells in adult tissue [54]. Clinical studies showed that VSEL-SCs, which represent a pool of mobile stem cells, could be mobilized in the peripheral blood upon hypoxia-associated injuries, such as stroke [55] and acute myocardial infarction [56]. The role of VSEL-SCs will need to be further investigated.

\section{Stem Cell Therapy in OIR}

Using animal models of ROP, a number of groups revealed that different populations of stem cells could promote vascular repair [5763]. By intravitreal injection of adult mouse bone marrow-derived lineage negative ( $\mathrm{Lin}^{-}$) or $\mathrm{CD} 44$ (hyaluronic acid receptor)-rich myeloid progenitor cells in the mouse OIR model, Ritter et al. [57] found that these not only were able to migrate to the avascular regions of the neonatal retina, but also had the ability to differentiate into microglia. Normalization of vasculature was further confirmed by a significant reduction of the obliterated and neovascular areas in the retina of the transplanted animals. In order to examine the potential longterm side effects of the transplantation, morphological and functional studies were carried out. No teratoma, tumor, or abnormality in the different retinal layers was observed in the transplanted retina. In addition, no difference in the light-adapted cone or dark-adapted rod 


\begin{tabular}{|c|c|c|c|}
\hline $\begin{array}{l}\text { Type of stem cell } \\
\text { Animal models }\end{array}$ & Origin of stem cells & Experimental outcomes in animal models or clinical studies & Potential therapeutic use \\
\hline Animal models & & & \\
\hline $\begin{array}{l}\text { Lin or CD44-rich myeloid } \\
\text { progenitor cells [57] }\end{array}$ & Mouse bone marrow & $\begin{array}{l}\text { Iransplanted cells migrated to the avascular regions of the retina and } \\
\text { differentiated into microglia in a mouse OIR model } \\
\text { Reduced the obliterated and neovascular areas in a mouse OIR model }\end{array}$ & ROP \\
\hline $\begin{array}{l}\text { OECs (CD31+ CD34+ CD146 }{ }^{+} \text {CD14 } \\
\text { CD45) }[61]\end{array}$ & Human peripheral blood & $\begin{array}{l}\text { Transplanted cells incorporated into the resident retinal vasculature } \\
\text { and assisted in retinal vascular remodeling with formation of tubes in a } \\
\text { mouse OIR model } \\
\text { Reduced the avascular and neovascular areas in a mouse OIR model }\end{array}$ & ROP \\
\hline $\begin{array}{l}\text { eEPCs (CD14+CD31+CD45+CD34- } \\
\text { CD117-CD133-CD146-) [61] }\end{array}$ & Human peripheral blood & $\begin{array}{l}\text { Minimal proliferative capacity in a mouse OIR model } \\
\text { Lack of tube-formation capacity in a mouse OIR model }\end{array}$ & ROP \\
\hline EPCs $($ Lin-Sca-1+1 $)[59]$ & Mouse bone marrow & $\begin{array}{l}\text { Transplanted cells incorporated in vascular tufts in addition to the intact } \\
\text { region in a mouse OIR model }\end{array}$ & ROP \\
\hline Lin- myeloid progenitor cells [58] & Mouse bone marrow & $\begin{array}{l}\text { Transplanted cells selectively migrated to the injured site and targeted } \\
\text { the activated glial cells upon laser or mechanical injury } \\
\text { Transplantation of cells ceased the spontaneous degeneration of } \\
\text { vasculature in transgenic } r d / r d \text { neonatal mice }\end{array}$ & Retinal degeneration \\
\hline Mixed OECs and eEPCs [63] & Human peripheral blood & $\begin{array}{l}\text { Synergistically promoted vessel formation in a mouse hind limb ischemic } \\
\text { model }\end{array}$ & $\begin{array}{l}\text { Revascularization in ischemic } \\
\text { tissue }\end{array}$ \\
\hline MIO cells [46] & Human retina & $\begin{array}{l}\text { Transplanted cells migrated into the ONL, INL and GCL in normal } \\
\text { neonatal Lister hooded rats }\end{array}$ & Retinal degeneration \\
\hline $\begin{array}{l}\text { Very small embryonic/epiblast-like } \\
\left.\text { stem cells (Sca- } 1^{+} \text {Lin-CD45-) }^{-} 48\right]\end{array}$ & Neonatal mouse retina & $\begin{array}{l}\text { Differentiated into cells expressing markers of the three embryonic } \\
\text { layers in vitro }\end{array}$ & $\begin{array}{l}\text { Cell type identified but potential } \\
\text { use currently unknown }\end{array}$ \\
\hline Clinical studies & & & \\
\hline EPCs $\left(C D 34^{+} \mathrm{CD} 133^{+} \mathrm{CD} 144^{+}\right)[49]$ & Human peripheral blood & $\begin{array}{l}\text { Increase in preterm patients } \\
\text { Higher in patients with ROP than those without }\end{array}$ & $\begin{array}{l}\text { Cell type identified but potential } \\
\text { use currently unknown }\end{array}$ \\
\hline $\begin{array}{l}\text { VSEL-SCs (Lin-CXCR4+CD45-) } \\
{[49,55,56]}\end{array}$ & Human peripheral blood & $\begin{array}{l}\text { Increase in preterm patients } \\
\text { Found in peripheral blood upon hypoxia-associated injuries }\end{array}$ & $\begin{array}{l}\text { Cell type identified but } \\
\text { potential use currently unknown }\end{array}$ \\
\hline Limbal stem cells $[41,42]$ & Human limbus & $\begin{array}{l}\text { Permanent restoration of transparent corneal epithelium (10 year follow- } \\
\text { up studies) }\end{array}$ & Limbal stem cell deficiency \\
\hline
\end{tabular}

Table 2: A summary of the experimental outcomes as well as the potential therapeutic use of various types of stem cells in animal models and clinical studies.

ERG responses was observed in the transplanted eye when compared with the OIR controls 6 months after transplantation. However, when bone marrow-derived $\mathrm{CD} 44^{+}$cells with targeted deletion of hypoxiainducible factor-1 $\alpha$ (HIF-1 $\alpha$ ) in the myeloid lineage were applied in the OIR model, the rescue effects were abolished. This suggested that the expression of myeloid-specific HIF-1 1 was required to promote the vascular repair. Moreover, injection of Lin myeloid progenitor cells to P2 neonatal mice showed that these cells homed to astrocytes in the early stage (P6) and incorporated into the retinal vasculature during the later stage (P9- P16) of retinal development [58]. Upon retinal injuries by photocoagulation or needle tip in adult mice, these injected cells selectively migrated to the injured site and targeted the activated glial cells. When Lin myeloid progenitor cells were injected to transgenic $r d / r d$ neonatal mice, the spontaneous degeneration of vasculature was ceased while preserving the normal vasculature [58].

The incorporation ability of another sub-group of myeloid progenitor cells (Lin-Sca- $1^{+}$, also called bone marrow-derived EPCs) in mouse OIR model was also reported by Nakagawa et al. [59]. In this study, the cells were injected into the irradiated neonatal mice via temporal facial vein. The transplanted cells, which were co-stained with CD11b (a leukocyte/monocyte marker) and with arborescent shape, were detectable outside the retinal vessels. Although the number of incorporated cells was attenuated in the intact vascular network of the OIR mice on P12 when compared with the controls, it reached the same level on P17. Interestingly, almost an equivalent amount of cells was also found to incorporate into vascular tufts in the OIR mice, suggesting that they may play a role in conversion of the pathologic microvasculature to intact vascular network.

Another candidate in cell-based therapy for ROP is EPCs derived from myeloid stem cells [60]. Due to the nature of heterogeneity of these cells, Medina et al. [61] isolated two sub-groups of EPCs, outgrowth endothelial cells (OECs) and early EPCs (eEPCs), from human peripheral blood and studied their therapeutic potential in ischemic retinopathy using the mouse OIR model. Both OECs and
eEPCs expressed CD31 endothelial marker. Hematopoietic markers, such as CD45 and CD14, were absent in OECs but were abundant in eEPCs whereas the expression of stem cell-associated surface markers, CD34, CD133 and CD117, are higher in the OECs when compared with those in eEPCs [61,62]. At 3 days after intravitreal injection of OECs, significant incorporation of OECs was observed in the resident retinal vasculature together with tube formation, which assisted in retinal vascular remodeling, in the ischemic region. The reduction of pathologic neovascularization in the OECs-treated retina further demonstrated the vascular repair ability of OECs in OIR. On the contrary, eEPCs only had minimal proliferative capacity and lacked tube-forming capacity in this study [61].

Moreover, Yoon et al. [63] showed that transplantation of the mixed populations of EPCs, OECs and eEPCs, synergistically promoted vessel formation in a mouse hind limb ischemic model. Both sub-groups of EPCs expressed VEGF receptors. IL-8 and matrix metalloproteinases (MMP)-9 were found to be secreted by eEPCs while MMP-2 was mainly secreted by OECs. The authors proposed that the OECs might act as a building block while the eEPCs contribute to the neovascularization. In fact, cross-talk by the secreted cytokines or other factors may exist between the two types of EPCs.

In summary, the therapeutic potential of stem cells in ROP was evident in the above animal studies, in which the pathologic vasculature observed in mouse OIR model was normalized after stem cell treatment. A summary of the potential use of various types of stem cells is provided in Table 2 .

\section{Future Prospective}

Owing to the promising experimental results obtained in the animal OIR models, stem cell therapy could represent an alternative treatment for ROP in preterm infants. Transplantation of autologous bone marrow-derived stem/progenitor cells from the newborns, however, is traumatic and unfeasible due to the health status of the preterm infants and the invasive procedures in harvesting the bone marrow. 
Although the use of allogenic bone marrow with matched human leukocyte antigens (HLA) can overcome this problem, the potential of graft rejection cannot be excluded. On the other hand, autologous EPCs can be isolated from peripheral blood and expanded in vitro, thereby allowing subsequent transplantation. Another potential source of stem cells comes from umbilical cord blood (UCB), which contains a reservoir of a variety of stem cells, including VSEL-SCs [51], mesenchymal stem cell, hematopoietic stem cells and cord blood-derived embryonic-like stem cells [64]. Based on the phenotypic specificities of the stem cell sub-populations in the animal studies, they can be used as a reference for identification and isolation from the UCB. UCB is abundant, easily to harvest without harming the donors and ethical to use [65]. Further in vivo studies using these selected cells allow us to have a better insight of UCB as the alternative source of stem cells in ROP.

\section{Conclusion}

The incidence of preterm birth and its associated retinal prematurity are unavoidable. The emergence of stem cells therapy provides a potential alternative treatment for ROP. A number of studies showed that stem cells have regenerative ability, not only by direct differentiation and incorporation into the vasculature but also via a paracrine manner on the residential cells, thereby promoting normal vascularization in animal OIR models. Stem cell therapy as a medical treatment has ushered in a new era.

\section{References}

1. Terry TL (1942) Fibroblastic Overgrowth of Persistent Tunica Vasculosa Lentis in Infants Born Prematurely: II Report of Cases-Clinical Aspects. Trans Am Ophthalmol Soc 40: 262-284.

2. Gilbert C, Foster A (2001) Childhood blindness in the context of VISION 2020-the right to sight. Bull World Health Organ 79: 227-232.

3. Oyster CW, Retina I (1999) Photoreceptors and Functional Organization., in The Human Eye: Structure and Function, Sinauer Associates: Sunderland, Massachusetts.

4. Osborne NN, Casson RJ, Wood JP, Chidlow G, Graham M, et al. (2004) Retinal ischemia: mechanisms of damage and potential therapeutic strategies. Prog Retin Eye Res 23: 91-147.

5. Antonetti DA, Lieth E, Barber AJ, Gardner TW (1999) Molecular mechanisms of vascular permeability in diabetic retinopathy. Semin Ophthalmol 14: 240-248.

6. Sapieha P, Joyal JS, Rivera JC, Kermorvant-Duchemin E, Sennlaub F, et al. (2010) Retinopathy of prematurity: understanding ischemic retinal vasculopathies at an extreme of life. J Clin Invest 120: 3022-3032.

7. Hellstrom A, Engstrom E, Hard AL, Albertsson-Wikland K, Carlsson B, et al (2003) Postnatal serum insulin-like growth factor I deficiency is associated with retinopathy of prematurity and other complications of premature birth. Pediatrics 112: 1016-1020.

8. Chen J, Stahl A, Hellstrom A, Smith LE (2011) Current update on retinopathy of prematurity: screening and treatment. Curr Opin Pediatr 23: 173-178.

9. Tasman W (2011) Retinopathy of prematurity: do we still have a problem?: the Charles L. Schepens lecture. Arch Ophthalmol 129: 1083-1086.

10. Roth AM (1977) Retinal vascular development in premature infants. Am J Ophthalmol 84: 636-640.

11. Chen J, Smith LE (2007) Retinopathy of prematurity. Angiogenesis 10: 133-140.

12. Kanski JJ (2007) Clinical Ophthalmology: a Systematic Approach. 6th ed Edinburgh: Butterworth-Heinemann/Elsevier.

13. Rubaltelli DM, Hirose T (2008) Retinopathy of prematurity update. Int Ophthalmol Clin 48: 225-235.

14. O'Connor AR, Stephenson T, Johnson A, Tobin MJ, Moseley MJ, et al. (2002) Long-term ophthalmic outcome of low birth weight children with and without retinopathy of prematurity. Pediatrics 109: 12-18.
15. Fletcher EL, Downie LE, Hatzopoulos K, Vessey KA, Ward MM, et al. (2010) The significance of neuronal and glial cell changes in the rat retina during oxygen-induced retinopathy. Doc Ophthalmol 120: 67-86.

16. Fulton AB, Hansen RM (1996) Photoreceptor function in infants and children with a history of mild retinopathy of prematurity. J Opt Soc Am A Opt Image Sci Vis 13: $566-571$

17. Fulton AB, Hansen RM, Moskowitz A (2009) Development of rod function in term born and former preterm subjects. Optom Vis Sci 86: E653-658.

18. Hansen RM, Harris ME, Moskowitz A, Fulton AB (2010) Deactivation of the rod response in retinopathy of prematurity. Doc Ophthalmol 121: 29-35.

19. Harris ME, Moskowitz A, Fulton AB, Hansen RM (2011) Long-term effects of retinopathy of prematurity (ROP) on rod and rod-driven function. Doc Ophthalmol 122: 19-27.

20. Fulton AB, Hansen RM, Petersen RA, Vanderveen DK (2001) The rod photoreceptors in retinopathy of prematurity: an electroretinographic study. Arch Ophthalmol 119: 499-505.

21. Fulton AB, Hansen RM, Moskowitz A, Barnaby AM (2005) Multifocal ERG in subjects with a history of retinopathy of prematurity. Doc Ophthalmol 111: 7-13.

22. Clark D, Mandal K (2008) Treatment of retinopathy of prematurity. Early Hum Dev 84: 95-99.

23. Harder BC, von Baltz S, Jonas JB, Schlichtenbrede FC (2011) Intravitrea bevacizumab for retinopathy of prematurity. J Ocul Pharmacol Ther 27: p. 623-627.

24. Lee SJ, Kim SY, Yoo BC, Kim HW, Kim YH (2011) Plamsma level of vascular endothelial growth factor in retinopathy of prematurity after intravitreal injection of Bevacizumab, ARVO: Fort Lauderdale.

25. Micieli JA, Surkont M, Smith AF (2009) A systematic analysis of the off-label use of bevacizumab for severe retinopathy of prematurity. Am J Ophthalmol 148: 536-543.

26. Gariano RF (2010) Special features of human retinal angiogenesis. Eye 24 401-407.

27. Smith LE, Wesolowski E, McLellan A, Kostyk SK, D'Amato R, et al. (1994) Oxygeninduced retinopathy in the mouse. Invest Ophthalmol Vis Sci 35: 101-111.

28. Penn JS, Henry MM, Tolman BL (1994) Exposure to alternating hypoxia and hyperoxia causes severe proliferative retinopathy in the newborn rat. Pediatr Res 36: 724-31.

29. Connor KM, Krah NM, Dennison RJ, Aderman CM, Chen J, et al. (2009) Quantification of oxygen-induced retinopathy in the mouse: a model of vessel loss, vessel regrowth and pathological angiogenesis. Nat Protoc 4: 1565-1573.

30. Fulton AB, Reynaud X, Hansen RM, Lemere CA, Parker C, et al. (1999) Rod photoreceptors in infant rats with a history of oxygen exposure. Invest Ophthalmol Vis Sci 40: 168-74.

31. Liu K, Akula JD, Falk C, Hansen RM, Fulton AB (2006) The retinal vasculature and function of the neural retina in a rat model of retinopathy of prematurity. Invest Ophthalmol Vis Sci 47: 2639-47.

32. Reynaud X, Hansen RM, Fulton AB (1995) Effect of prior oxygen exposure on the electroretinographic responses of infant rats. Invest Ophthalmol Vis Sci 36: 2071-9.

33. Vessey KA, Wilkinson-Berka JL, Fletcher EL (2011) Characterization of retinal function and glial cell response in a mouse model of oxygen-induced retinopathy. J Comp Neurol 519: 506-27.

34. Coombs JL, Van Der List D, Chalupa LM (2007) Morphological properties of mouse retinal ganglion cells during postnatal development. J Comp Neurol 503: 803-14.

35. Stahl A, Connor KM, Sapieha P, Chen J, Dennison RJ, et al. (2010) The mouse retina as an angiogenesis model. Invest Ophthalmol Vis Sci 51: 2813-26.

36. Davanger M, Evensen A (1971) Role of the pericorneal papillary structure in renewal of corneal epithelium. Nature 229: 560-561.

37. Schermer A, Galvin S, Sun TT (1986) Differentiation-related expression of a major $64 \mathrm{~K}$ corneal keratin in vivo and in culture suggests limbal location of corneal epithelial stem cells. J Cell Biol 103: 49-62.

38. Cotsarelis G, Cheng SZ, Dong G, Sun TT, Lavker RM (1989) Existence of slow-cycling limbal epithelial basal cells that can be preferentially stimulated to proliferate: implications on epithelial stem cells. Cell 57: 201-209. 
39. Raviola G (1982) Schwalbe line's cells: a new cell type in the trabecular meshwork of Macaca mulatta. Invest Ophthalmol Vis Sci 22: 45-56.

40. Acott TS, Samples JR, Bradley JM, Bacon DR, Bylsma SS, et al. (1989) Trabecular repopulation by anterior trabecular meshwork cells after laser trabeculoplasty. Am J Ophthalmol 107: 1-6.

41. Rama P, Matuska S, Paganoni G, Spinelli A, De Luca M, et al. (2010) Limbal stem-cell therapy and long-term corneal regeneration. N Engl J Med 363: 147-155.

42. Sangwan VS, Basu S, Vemuganti GK, Sejpal K, Subramaniam SV, et al (2011) Clinical outcomes of xeno-free autologous cultivated limbal epithelial transplantation: a 10-year study. Br J Ophthalmol 95: 1525-1529.

43. Tropepe V, Coles BL, Chiasson BJ, Horsford DJ, Elia AJ, et al. (2000) Retinal stem cells in the adult mammalian eye. Science 287: 2032-2036.

44. Yang P, Seiler MJ, Aramant RB, Whittemore SR (2002) In vitro isolation and expansion of human retinal progenitor cells. Exp Neurol 177: 326-331.

45. Limb GA, Salt TE, Munro PM, Moss SE, Khaw PT (2002) In vitro characterization of a spontaneously immortalized human Muller cell line (MIO-M1). Invest Ophthalmol Vis Sci 43: 864-869.

46. Lawrence JM, Singhal S, Bhatia B, Keegan DJ, Reh TA, et al. (2007) MIO-M1 cells and similar muller glial cell lines derived from adult human retina exhibit neural stem cell characteristics. Stem Cells 25: 2033-2043.

47. Bhatia B, Singhal S, Lawrence JM, Khaw PT, Limb GA (2009) Distribution of Muller stem cells within the neural retina: evidence for the existence of a ciliary margin-like zone in the adult human eye. Exp Eye Res 89: 373-382.

48. Liu Y, Gao L, Zuba-Surma EK, Peng X, Kucia M, et al. (2009) Identification of small Sca-1(+), Lin(-), CD45(-) multipotential cells in the neonatal murine retina. Exp Hematol 37: 1096-107.

49. Machalinska A, Modrzejewska M, Kotowski M, Dziedziejko V, Kucia M, et al. (2010) Circulating stem cell populations in preterm infants: implications for the development of retinopathy of prematurity. Arch Ophthalmol 128: 1311-1319.

50. Kucia M, Zuba-Surma EK, Wysoczynski M, Wu W, Ratajczak J, et al. (2007) Adult marrow-derived very small embryonic-like stem cells and tissue engineering. Expert Opin Biol Ther 7: 1499-514.

51. Kucia M, Halasa M, Wysoczynski M, Baskiewicz-Masiuk M, Moldenhawer S, et al. (2007) Morphological and molecular characterization of novel population of CXCR4+ SSEA-4+ Oct-4+ very small embryonic-like cells purified from human cord blood: preliminary report. Leukemia 21: 297-303.

52. Ratajczak MZ, Zuba-Surma EK, Machalinski B, Ratajczak J, Kucia M (2008) Very small embryonic-like (VSEL) stem cells: purification from adult organs, characterization, and biological significance. Stem Cell Rev 4: 89-99.
53. Zuba-Surma EK, Kucia M, Wu W, Klich I, Lillard JW Jr, et al. (2008) Very small embryonic-like stem cells are present in adult murine organs: ImageStreambased morphological analysis and distribution studies. Cytometry A 73A: 1116-27.

54. Ratajczak MZ, Machalinski B, Wojakowski W, Ratajczak J, Kucia M (2007) A hypothesis for an embryonic origin of pluripotent Oct-4(+) stem cells in adult bone marrow and other tissues. Leukemia 21: 860-7.

55. Paczkowska E, Kucia M, Koziarska D, Halasa M, Safranow K, et al. (2009) Clinical evidence that very small embryonic-like stem cells are mobilized into peripheral blood in patients after stroke. Stroke 40: 1237-1244.

56. Wojakowski W, Tendera M, Kucia M, Zuba-Surma E, Paczkowska E, et al (2009) Mobilization of bone marrow-derived Oct-4+ SSEA-4+ very small embryonic-like stem cells in patients with acute myocardial infarction. J Am Coll Cardiol 53: 1-9.

57. Ritter MR, Banin E, Moreno SK, Aguilar E, Dorrell MI, et al. (2006) Myeloid progenitors differentiate into microglia and promote vascular repair in a model of ischemic retinopathy. J Clin Invest 116: 3266-3276.

58. Otani A, Kinder K, Ewalt K, Otero FJ, Schimmel P, et al. (2002) Bone marrowderived stem cells target retinal astrocytes and can promote or inhibit retina angiogenesis. Nat Med 8: 1004-1010.

59. Nakagawa $Y$, Masuda $H$, Ito R, Kobori M, Wada M, et al. (2011) Aberrant kinetics of bone marrow-derived endothelial progenitor cells in the murine oxygen-induced retinopathy model. Invest Ophthalmol Vis Sci 52: 7835-41.

60. Urbich C, Dimmeler S (2004) Endothelial progenitor cells: characterization and role in vascular biology. Circ Res 95: 343-353.

61. Medina RJ, O'Neill CL, Humphreys MW, Gardiner TA, Stitt AW (2010) Outgrowth endothelial cells: characterization and their potential for reversing ischemic retinopathy. Invest Ophthalmol Vis Sci 51: 5906-5913.

62. Stitt AW, O'Neill CL, O'Doherty MT, Archer DB, Gardiner TA, et al. (2011) Vascular stem cells and ischaemic retinopathies. Prog Retin Eye Res 30: 149-166.

63. Yoon CH, Hur J, Park KW, Kim JH, Lee CS, et al. (2005) Synergistic neovascularization by mixed transplantation of early endothelial progenitor cells and late outgrowth endothelial cells: the role of angiogenic cytokines and matrix metalloproteinases. Circulation 112: 1618-27.

64. Lee MW, Jang IK, Yoo KH, Sung KW, Koo HH (2010) Stem and progenitor cells in human umbilical cord blood. Int J Hematol 92: 45-51.

65. Rubinstein P, Rosenfield RE, Adamson JW, Stevens CE (1993) Stored placental blood for unrelated bone marrow reconstitution. Blood 81: 1679-1690.

Submit your next manuscript and get advantages of OMICS Group submissions

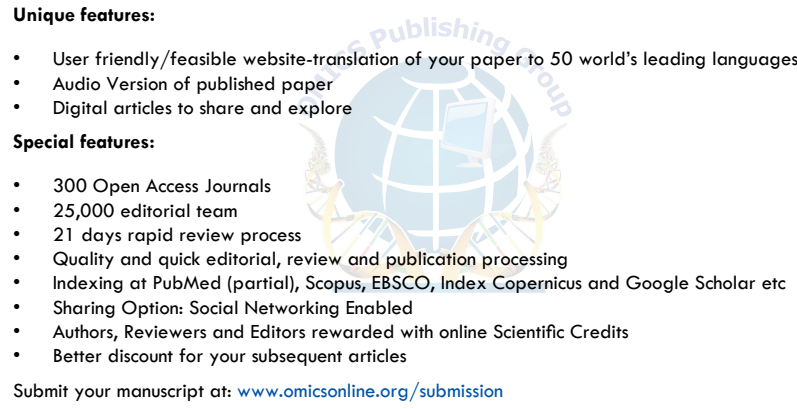

